\title{
PENGARUH TERAPI SUPORTIF TERHADAP KECEMASAN DAN MOTIVASI KELUARGA DALAM MERAWAT ANAK RETARDASI MENTAL RINGAN DI SLB DHARMA ASIH KRAKSAAN PROBOLINGGO
}

\author{
Rizka Yunita ${ }^{1}$ \\ Program Studi Profesi Ners, Stikes Hafshawaty Pesantren Zainul Hasan \\ *Email: rizkayunita10@gmail.com
}

\begin{abstract}
Abstrak
Retardasi mental (RM) merupakan suatu kondisi klinis yang bersifat sangat kompleks dimana individu memiliki tingkat intelegensi (IQ) rendah. Hal ini menyebabkan anak mengalami keterbatasan dalam berkomunikasi, kesulitan mengendalikan gerakan motorik kasar maupun halus dan tidak mampu memenuhi kebutuhan diri sehingga membutuhkan bantuan dan tergantung kepada keluarga. Jika keluarga tidak mampu memberikan waktu dan perhatian lebih maka dapat menimbulkan kecemasan. Kecemasan yang dialami keluarga dapat berdampak pula terhadap motivasi keluarga merawat anak RM ringan. Tujuan penelitian adalah menganalisa pengaruh terapi suportif terhadap kecemasan dan motivasi keluarga dalam merawat anak retardasi mental ringan. Penelitian menggunakan desain quasy eksperimental dengan one group pre post test design. Populasi dan sampel penelitian adalah keluarga yang mempunyai anak RM ringan. Teknik pengambilan sampel menggunakan total sampling. Hasil penelitian didapatkan skor kecemasan keluarga dalam merawat anak RM ringan sebelum diberikan terapi suportif adalah 86,75 sedangkan sesudah 37,83. Skor motivasi keluarga dalam merawat anak RM ringan sebelum diberikan terapi suportif yakni 18,67 dan sesudah 42,12. Sementara itu, nilai signifikansi kecemasan sebesar $\rho=0,000$ sehingga terdapat pengaruh terapi suportif terhadap kecemasan keluarga dalam merawat anak RM ringan. Selain itu, nilai signifikansi motivasi sebesar $\rho=0,000$ sehingga terdapat pengaruh terapi suportif terhadap motivasi keluarga dalam merawat anak RM ringan.
\end{abstract}

Kata Kunci: kecemasan, motivasi, keluarga, retardasi mental ringan, terapi suportif

\begin{abstract}
Mental retardation (RM) is a very complex clinical condition in which individuals have a low level of intelligence (IQ). This causes children to experience limitations in communication, difficulty in controlling gross and fine motor movements and not being able to fulfill their needs so they need help and depend on the family. If the family is unable to give more time and attention, it can cause anxiety. Anxiety experienced by the family can also have an impact on the motivation of the family to care for mild RM children. The aim of the study was to analyze the effect of supportive therapy on family anxiety and motivation in treating children with mild mental retardation. The study used experimental quasy design with one group pre post test design. Population and research sample are families who have mild RM children. The sampling technique uses total sampling. The results showed that family anxiety scores in treating mild RM children before being given supportive therapy were 86.75 while after 37.83. Meanwhile, the score of family motivation in caring for children with mild RM before being given supportive therapy is 18.67 and after 42.12. Meanwhile, the significance value of anxiety was $\rho=0,000$ so that there was an effect of supportive therapy on family anxiety in treating mild RM children. In addition, the significance value of motivation is $\rho=0,000$ so that there is a supportive therapentic effect on the motivation of families in caring for mild RM children.
\end{abstract}

Keywords: anxiety, motivation, family, mild mental retardation, supportive therapy

\section{Pendahuluan}

Retardasi mental ringan merupakan

suatu kondisi klinis yang bersifat sangat kompleks dimana individu memiliki tingkat intelegensi (IQ) rendah berkisar antara 50-69 (Roy, 2012). Retardasi mental 
Rizka. Y, Pengaruh Terapi Suportif Terhadap Kecemasan Dan Motivasi Keluarga Dalam Merawat Anak Retardasi Mental Ringan Di Slb Dharma Asih Kraksaan Probolinggo ringan sering terjadi pada usia anak-anak total populasi anak penyandang disabilitas. sebagai akibat proses patologis yang terjadi di dalam otak sehingga menyebabkan seseorang mengalami keterbelakangan mental dan kecacatan seumur hidup dan berakibat keterlambatan tumbuh kembang terutama dari segi intelektual (Vashist \& Yadav, 2011).

Berdasarkan hasil penelitian yang dilakukan oleh Katalinic, Jengic, Pavelic dan Zudenigo (2012) menyatakan bahwa saat ini jumlah penderita retardasi mental secara global diperkirakan telah mencapai 1-3\% dari jumlah populasi seluruh penduduk di dunia. Sekitar $87 \%$ anak mengalami retardasi mental ringan, sebanyak $11-12 \%$ retardasi mental sedang dan $1-2 \%$ adalah retardasi mental berat. Sementara itu, pada tahun 2013 telah mencapai $324(48,15 \%)$ populasi anak retardasi mental ringan, tipe sedang sebanyak $29 \%$, berat berkisar $14,2 \%$ dan sangat berat sebesar 8,6\% (Ramakrishna \& Bhagya, 2013).

\section{Hasil Survei Kementerian}

Kesehatan RI (2014) melaporkan bahwa populasi anak retardasi mental di Indonesia telah menempati urutan kedua dari sepuluh kategori anak disabilitas lainnya. Penyandang retardasi mental telah mencapai 30.460 anak setelah urutan pertama ditempati oleh populasi tunadaksa yang mencapai 32.990 anak dari 130.572

Sementara itu, di wilayah provinsi Jawa Timur pada tahun 2014, prevalensi anak retardasi mental mencapai $6.633(61,21 \%)$ dari populasi seluruh anak disabilitas yang terdiri dari retardasi mental ringan sejumlah $3.994(60,22 \%)$ dan sedang sebanyak 2639 (39,78\%).

Anak dengan retardasi mental ringan secara psikologis dan sosial dapat menjadi stressor bagi dirinya sendiri, anggota keluarga dan masyarakat (Vashist \& Yadav, 2011). Hal ini disebabkan karena keterbatasan kemampuan anak dalam berkomunikasi, mengurus diri sendiri, bersosialisasi, berinteraksi dengan komunitas, sulit dalam mengendalikan gerakan motorik kasar maupun halus, tidak mampu dalam menjaga keamanan diri sendiri, dan tidak mampu dalam bekerja atau mengerjakan sesuatu (Sadock, 2010; Roy, 2012). Oleh karena itu, anak retardasi mental ringan sangat memerlukan bantuan dan tergantung kepada keluarga agar dapat bertahan hidup, tumbuh dan berkembang secara optimal walaupun dengan keterbatasan.

Keluarga dituntut untuk dapat memberikan perawatan secara khusus dibandingkan dengan anak-anak pada umumnya (Rohini, 2012). Keluarga harus rela dan bersedia untuk meluangkan waktu dan energi lebih guna membantu anak 
Rizka. Y, Pengaruh Terapi Suportif Terhadap Kecemasan Dan Motivasi Keluarga Dalam Merawat Anak Retardasi Mental Ringan Di Slb Dharma Asih Kraksaan Probolinggo memenuhi kebutuhannya sehari-hari suatu permasalahan. Jenaabadi (2014) juga (Abedin \& Molaie, 2010; Karasavvidis et al, 2011). Jika keluarga tidak mampu beradaptasi maka akan membuatnya merasa lelah sehingga berpengaruh terhadap sistem parental akibatnya keluarga merasa mendapatkan tekanan lebih dalam yang berdampak pada ketidakstabilan sistem keluarga menyebabkan kondisi emosional dan pola pikir menjadi abnormal sehingga muncul masalah psikososial yakni kecemasan (Gohel, Mukherjee \& Choudhary, 2011; Hosseinkhanzadeh et al, 2013).

Pernyataan tersebut sesuai dengan hasil penelitian yang telah dilakukan oleh Azeem, et al (2013) memaparkan bahwa di Pakistan, sebanyak $77 \%$ keluarga mengalami kecemasan saat merawat anak dengan retardasi mental. Penelitian serupa juga dilakukan oleh Solomon (2015) yang menyatakan bahwa sebanyak 23,3\% mengalami kecemasan tingkat berat, $14 \%$ mengalami kecemasan tingkat sedang, dan $3,5 \%$ mengalami kecemasan tingkat ringan. Sedangkan sisanya yakni 15,2\% responden mampu menerima keadaan anak dengan retardasi mental.

Menurut, Hosseinkhanzadeh, et al (2013) menyebutkan bahwa kecemasan dapat muncul sebagai dampak dari kegagalan seseorang didalam memaknai dan mengendalikan emosi saat menghadapi menguraikan bahwa kecemasan dapat muncul sebagai akibat dari sulitnya menerima kehadiran anak retardasi mental sehingga menimbulkan kepenatan dan keletihan ketika memberikan perawatan kepada anak. Selain itu, adanya stigma masyarakat yang menganggap bahwa anak retardasi mental merupakan suatu aib bagi keluarga sehingga mendorong keluarga untuk lebih memilih menyembunyikan anak mereka dari masyarakat.

Menurut Ganzory, Matty dan Reheem (2013) juga menambahkan bahwa selain permasalahan diatas, kecemasan yang dialami keluarga juga disebabkan karena kekhawatiran terhadap masa depan anak, perlindungan kehidupan anak dan perawatan di masa depan. Perasaan inilah sering sekali menimbulkan rasa bersalah pada diri keluarga sebab membiarkan anak mengalami kecacatan. Keluarga juga merasa kecewa dan putus asa karena anak mereka tidak mampu untuk mencapai citacita yang telah diinginkan sebelumnya oleh keluarga sehingga membuatnya rentan mengalami cemas disebabkan adanya rasa malu, gelisah, frustasi dan tidak berdaya (Tavakolizadeh, Dashti \& Panahi, 2012; Azeem et al, 2013).

Kecemasan yang dialami keluarga akan berdampak pula terhadap motivasi keluarga dalam melakukan perawatan 
Rizka. Y, Pengaruh Terapi Suportif Terhadap Kecemasan Dan Motivasi Keluarga Dalam Merawat Anak Retardasi Mental Ringan Di Slb Dharma Asih Kraksaan Probolinggo kepada anak. Pernyataan tersebut sesuai mencapai tujuan. Selain itu, motivasi juga dengan hasil penelitian kuantitatif yang dilakukan oleh Sari, Jumaini, Hasanah (2013) di Pekanbaru, Riau menunjukkan bahwa motivasi keluarga dalam merawat anak retardasi mental berada pada skor 45.36-47.67 sehingga termasuk dalam kategori motivasi rendah. Dengan demikian, mayoritas keluarga mengalami penurunan motivasi saat merawat anak retardasi mental.

Hal ini dikarenakan keluarga mengatakan bahwa penurunan motivasi terjadi akibat adanya sikap dan perilaku tidak terima terhadap kondisi anak yang mengalami keterbelakangan mental sehingga mereka merasa malu, putus asa dan pasrah. Kondisi inilah mendorong keluarga berpikir bahwa anak sudah tidak mampu memberikan kontribusi apapun. Akibatnya, keluarga enggan membimbing dan membatasi interaksi dengan anak sehingga tidak mampu mengoptimalkan perkembangannya. Perlakuan tersebut semakin memperlihatkan bahwa keluarga tidak memiliki motivasi lagi untuk memberikan perawatan secara maksimal pada anak (Hosseinkhanzadeh et al, 2013).

Motivasi dapat menurun pada saat seseorang tidak memperoleh dukungan dari sumber daya yang ada sehingga membuatnya mengalami kesulitan dalam menjalankan seluruh tugasnya guna dipengaruhi oleh kondisi psikologis dari seseorang. Ketika seseorang mengalami ketidakstabilan emosi seperti kecemasan maka menyebabkan lapang persepsi semakin menyempit sehingga perhatian seseorang hanya terpusat terhadap hal-hal yang spesifik dan tidak mampu menerima rangsangan dari luar sehingga menurunkan motivasi seseorang untuk melakukan suatu aktivitas (Tillery \& Fishbach, 2011).

Data hasil studi pendahuluan pada tanggal 03 April 2018 melalui hasil wawancara kepada 10 keluarga yang memiliki anak retardasi mental ringan di SLB Dharma Asih Kraksaan, Probolinggo didapatkan bahwa mayoritas keluarga merasa cemas, khawatir, gelisah, was-was dan malu saat mengantarkan anak ke sekolah. Selain itu, keluarga cenderung merasa kesal, jengkel dan merasa tidak sabar menasehati ketika anak menolak masuk kelas. Selain itu, keluarga merasa tidak termotivasi untuk mendidik anak sebab mereka mengalami kesulitan saat mendidik anak sehingga mereka seringkali menyalahkan diri, sering menangis, pasrah dan putus asa dengan masa depan anak. Hal ini terbukti bahwa sekitar 8 orang keluarga (80\%) mengalami kecemasan dan mengalami penurunan motivasi dalam merawat anak retardasi mental ringan. 
Rizka. Y, Pengaruh Terapi Suportif Terhadap Kecemasan Dan Motivasi Keluarga Dalam Merawat Anak Retardasi Mental Ringan Di Slb Dharma Asih Kraksaan Probolinggo

Dari uraian hasil studi pendahuluan di atas, maka diperlukan penanganan segera salah satunya melalui pemberian psikoterapi yakni terapi suportif (Stuart, 2013). Terapi suportif merupakan suatu terapi yang sangat diperlukan oleh keluarga terutama saat mengelola penyakit-penyakit kronis yang memerlukan perawatan seumur hidup salah satunya seperti kondisi retardasi mental. Terapi ini bekerja dengan cara meningkatkan kemampuan keluarga dalam merawat anak retardasi mental melalui pemanfaatan sumber dukungan yang dimiliki oleh keluarga (Kerenhappachu \& Sridevi, 2014; Gonca \& Deniz, 2016). Dalam

\section{Metode Penelitian}

Penelitian ini menggunakan desain penelitian quasy experimental dengan one group pre-post test design. Penelitian ini menggunakan populasi dan sampel yaitu keluarga yang memiliki anak dengan retardasi mental ringan sejumlah 34 orang sesuai kriteria inklusi dan eksklusi. Teknik sampling yang digunakan adalah total sampling. Penelitian ini dilaksanakan tanggal 14 Mei sampai 02 Juni 2018 di pelaksanaannya, terapi dilakukan secara berkelompok dan ditujukan kepada keluarga yang memiliki permasalahan yang sama sehingga dapat memberikan kesempatan kepada keluarga untuk mengungkapkan perasaan dan berbagi pengalaman merawat anak retardasi mental dengan anggota kelompok lainnya (Solanki, 2015).

Tujuan dari penelitian ini adalah untuk menganalisa pengaruh terapi suportif keluarga terhadap kecemasan dan motivasi keluarga dalam merawat anak retardasi mental di SLB Dharma Asih Kraksaan Probolinggo.

SLB Dharma Asih Kraksaan Probolinggo. Instrumen penelitian menggunakan kuesioner tentang kecemasan berdasarkan State Trait Anxiety Inventory (STAI) dan kuesioner motivasi berdasarkan Nursing Motives for Helping Score (N-MHS). Setelah peneliti mendapatkan data, selanjutnya peneliti melakukan analisa data menggunakan uji statistik yaitu paired $t$ test

\section{Hasil Dan Pembahasan}

\section{Karakteristik Responden}

Berikut ini adalah uraian hasil dari distribusi frekuensi karakteristik demografi responden penelitian sebagai berikut: 
Rizka. Y, Pengaruh Terapi Suportif Terhadap Kecemasan Dan Motivasi Keluarga Dalam Merawat Anak Retardasi Mental Ringan Di Slb Dharma Asih Kraksaan Probolinggo Tabel 1. Distribusi frekuensi karakteristik responden

\begin{tabular}{lccc}
\hline & Karakteristik & n & (\%) \\
\hline Usia & & \\
$26-35$ th & 18 & 53 \\
$36-45$ th & 14 & 41 \\
$46-55$ th & 2 & 6 \\
Jenis Kelamin & 34 & 100 \\
Perempuan & & \\
Pendidikan & 4 & 12 \\
SD & 18 & 53 \\
SMP & 12 & 35 \\
SMA & & \\
Pekerjaan & 26 & 76 \\
IRT/tidak bekerja & 8 & 24 \\
Wiraswasta & & \\
\hline
\end{tabular}

Berdasarkan tabel 1 didapatkan usia responden penelitian mayoritas berusia antara 26-35 tahun yakni sebanyak 18 orang $(53 \%)$, sedangkan usia terendah adalah pada usia 46-55 tahun sebanyak 2 orang $(6 \%)$. Sementara itu, mayoritas jenis kelamin responden penelitian adalah perempuan yakni sebanyak 34 orang (100\%). Responden penelitian juga sebagian besar mempunyai latar belakang pendidikan SMP sebanyak 18 orang (53\%) dan paling sedikit berpendidikan SD sebanyak 4 orang (12\%). Pekerjaan responden penelitian adalah ibu rumah tangga sebanyak 26 orang $(76 \%)$ dan sebagai wiraswasta sebanyak 8 orang $(24 \%)$.

\section{Uji Normalitas Kecemasan dan Motivasi Keluarga Dalam Merawat Anak Retardasi}

\section{Mental Ringan}

Tabel 2. Hasil Uji Normalitas Data Kecemasan dan Motivasi Keluarga Dalam Merawat Anak Retardasi Mental Ringan

\begin{tabular}{ccc}
\hline Variabel & $\mathbf{n}$ & $\begin{array}{c}\text { Shapiro-Wilk } \\
(\boldsymbol{\rho} \text {-value })\end{array}$ \\
\hline Kecemasan_pre test & 34 & 0,949 \\
Kecemasan_post test & 34 & 0,268 \\
Motivasi_pre test & 34 & 0,429 \\
Motivasi_post test & 34 & 0,203 \\
\hline
\end{tabular}

Berdasarkan tabel 2 didapatkan hasil uji normalitas data kecemasan pada saat sebelum diberikan intervensi terapi suportif adalah $\rho=0,949$ dan sesudah intervensi $\rho=0,268$. Sementara itu, motivasi pada saat sebelum diberikan intervensi $\rho=0,429$ dan sesudah intervensi $\rho=0,203$. Berdasarkan data tersebut, maka 
Rizka. Y, Pengaruh Terapi Suportif Terhadap Kecemasan Dan Motivasi Keluarga Dalam Merawat Anak Retardasi Mental Ringan Di Slb Dharma Asih Kraksaan Probolinggo didapatkan bahwa seluruh nilai uji shapiro $\quad 0,05$ artinya seluruh data mempunyai wilk mempunyai nilai signifikansi $(\rho) \geq \quad$ distribusi data normal.

\section{Pengaruh Terapi Suportif Terhadap Kecemasan Keluarga Dalam Merawat Anak Retardasi Mental Ringan}

Tabel 3. Skor Kecemasan Keluarga Dalam Merawat Anak Retardasi Mental Ringan Sebelum dan Sesudah Terapi Suportif

\begin{tabular}{|c|c|c|c|c|}
\hline Kecemasan & $\mathrm{N}$ & $x \pm S D$ & $\begin{array}{l}\text { Perbedaan Mean } \\
(\text { CI 95\%) }\end{array}$ & $\mathrm{p}$-value \\
\hline $\begin{array}{l}\text { Sebelum terapi } \\
\text { suportif }\end{array}$ & 34 & $85,94 \pm 8,77$ & \multirow{2}{*}{$\begin{array}{c}47,74 \\
(45,55-49,92)\end{array}$} & \multirow{2}{*}{0,000} \\
\hline $\begin{array}{l}\text { Sesudah terapi } \\
\text { suportif }\end{array}$ & 34 & $38,21 \pm 4,57$ & & \\
\hline
\end{tabular}

Berdasarkan hasil uji paired t-test pada tabel 3 didapatkan bahwa nilai signifikansi yakni sebesar $\rho=0,000$ artinya $\rho \leq 0,05$ sehingga dapat disimpulkan bahwa terdapat pengaruh terapi suportif terhadap kecemasan keluarga dalam merawat anak retardasi mental ringan.

\section{Pengaruh Terapi Suportif Terhadap Motivasi Keluarga Dalam Merawat Anak Retardasi Mental Ringan}

Tabel 4. Skor Motivasi Keluarga Dalam Merawat Anak Retardasi Mental Ringan Sebelum dan Sesudah Terapi Suportif

\begin{tabular}{lcccc}
\hline Motivasi & $\mathrm{n}$ & $\overline{\mathrm{x}} \pm \mathrm{SD}$ & $\begin{array}{c}\text { Perbedaan Mean } \\
(\text { CI 95\%) }\end{array}$ & $\mathrm{p}$-value \\
\hline $\begin{array}{l}\text { Sebelum terapi } \\
\text { suportif }\end{array}$ & 34 & $18,97 \pm 2,87$ & & \\
$\begin{array}{l}\text { Sesudah terapi } \\
\text { suportif }\end{array}$ & 34 & $42,29 \pm 5,91$ & $(24,60-22,04)$ & 0,000 \\
\hline
\end{tabular}

Berdasarkan hasil uji paired t-test pada tabel 4 diperoleh nilai signifikansi yakni sebesar $\rho=0,000$ artinya $\rho \leq 0,05$ sehingga dapat disimpulkan bahwa terdapat pengaruh terapi suportif terhadap motivasi keluarga dalam merawat anak retardasi mental ringan.

\section{Pembahasan}

\section{Pengaruh Terapi Suportif Terhadap}

Kecemasan Keluarga Dalam Merawat Anak Retardasi Mental Ringan

\begin{abstract}
Berdasarkan pada tabel 3 didapatkan data bahwa kecemasan responden penelitian dalam merawat anak retardasi mental ringan sebelum diberikan terapi suportif memiliki skor sebesar 85,94. Hal ini dikarenakan mayoritas responden penelitian mengalami kecemasan selama merawat anak dengan retardasi mental ringan. Responden penelitian merasa tidak tenang, kurang percaya diri, khawatir, merasa terbebani, bingung, dan merasa gagal saat merawat anak retardasi mental.
\end{abstract}


Rizka. Y, Pengaruh Terapi Suportif Terhadap Kecemasan Dan Motivasi Keluarga Dalam Merawat Anak Retardasi Mental Ringan Di Slb Dharma Asih Kraksaan Probolinggo

Situasi ini dipicu sebab responden merasa bersalah dan menyalahkan diri karena tidak mampu menjaga kondisi kesehatannya selama masa kehamilan sehingga menyebabkan anak mengalami retardasi mental ringan.

Anak retardasi mental ringan memiliki beberapa bentuk keterlambatan tumbuh kembang dibandingkan dengan anak pada umumnya. Anak retardasi mental ringan menunjukkan tingkat pemahaman yang rendah, penggunaan bahasa cenderung terlambat sehingga mengalami kesulitan ketika berbicara, mengalami kesulitan saat membaca dan menulis serta mengalami keterlambatan saat melakukan keterampilan-keterampilan praktis akibatnya tidak mampu memenuhi kebutuhan diri (Diagnostic and statistical manual of mental disorders V, 2013). Seluruh kondisi yang dialami oleh anak retardasi mental ringan akan bersifat menetap sampai masa dewasa kelak.

Tentunya, berdasarkan kondisi yang dialami oleh anak retardasi mental ringan dapat menimbulkan ketergantungan dan memerlukan bantuan dari orang lain terutama yaitu keluarga. Seperti hasil penelitian yang telah dilakukan Singh, Kumar, Sharma dan Nehra (2014) menyatakan bahwa keluarga yang mempunyai anak retardasi mental cenderung mereka tidak siap menerima kehadiran anak retardasi mental. Jika perasaan tersebut muncul secara terus menerus maka dapat menyebabkan ketidakstabilan emosional seperti menimbulkan perasaan cemas dan putus asa saat merawat anak.

Kecemasan dapat diartikan sebagai suatu respon psikologis yang menjadi pertanda adanya rangsangan atau stimulus yang tidak menyenangkan dari luar. Hal ini dapat menimbulkan adanya perasaan gelisah, takut, tidak berdaya, khawatir, merasa tidak aman dan nyaman terhadap suatu kondisi sekitar. Apabila seseorang mengalami kecemasan maka dapat mengakibatkan terjadi penurunan pada kualitas dan fungsi hidupnya. Jika situasi ini terjadi terus menerus maka dapat menyebabkan individu menjadi pasif dan menurunnya sifat empati terhadap orang lain (Brook, 2014; Townsend, 2014).

Apabila situasi ini dibiarkan begitu saja, maka lambat laun dapat menyebabkan keluarga mengalami penurunan kemauan dan ketertarikan dalam merawat anak retardasi mental ringan. Seperti yang diungkapkan oleh Shenai dan Wadia (2014) menyatakan bahwa setiap anak memiliki hak untuk mendapatkan perawatan yang terbaik dari keluarga. Hal ini dikarenakan perawatan merupakan kebutuhan dasar yang harus dipenuhi kepada setiap anak termasuk anak yang 
Rizka. Y, Pengaruh Terapi Suportif Terhadap Kecemasan Dan Motivasi Keluarga Dalam Merawat Anak Retardasi Mental Ringan Di Slb Dharma Asih Kraksaan Probolinggo mengalami keterbelakangan mental (WHO, 2013). Dengan demikian, untuk mengatasi permasalahan tersebut maka salah satunya adalah dengan memberikan psikoterapi yaitu terapi suportif.

Berdasarkan pada tabel 6 didapatkan hasil bahwa skor kecemasan keluarga dalam merawat anak retardasi mental ringan setelah diberikan terapi suportif mengalami penurunan sebanyak 47,73 sehingga menjadi 38,21. Selain itu, berdasarkan hasil uji paired t-test diperoleh nilai signifikansi sebesar $\rho=0,000$ artinya $\rho \leq 0,05$ sehingga dapat disimpulkan bahwa terdapat pengaruh terapi suportif terhadap kecemasan keluarga dalam merawat anak retardasi mental ringan.

Terapi suportif merupakan bentuk psikoterapi yang dilakukan secara berkelompok sehingga membantu individu untuk dapat membina hubungan sosial. Terapi suportif juga memberikan dukungan kepada seluruh anggota kelompok yang memiliki permasalahan yang sama sehingga menimbulkan perasaaan aman dan nyaman sebab orang lain dapat menerima kehadirannya dengan terbuka (Klingberg, Jakobi dan Wittorf (2010). Melalui terapi suportif, setiap individu diberikan kesempatan mengungkapkan perasaan dan permasalahan yang sedang dialami sehingga mereka mendapatkan empati dari anggota kelompok lainnya. Hal ini menyebabkan mereka merasa tenang karena memperoleh dukungan emosional dari orang lain (Singh, Sweta \& Kiran, 2017).

Berdasarkan uraian tersebut, maka dapat diketahui bahwa dengan terapi suportif yang dilaksanakan secara berkelompok ini dapat membuat responden semakin memahami bahwa bukan hanya dirinya saja yang memiliki anak retardasi mental ringan. Selain itu, melalui terapi suportif mengajarkan responden untuk mampu mengungkapkan segala permasalahan yang dialami saat merawat anak retardasi mental ringan secara leluasa. Sementara itu, anggota kelompok lainnya mendengarkan secara seksama dan memberikan tanggapan serta berbagi solusi mengenai tindakan yang mereka lakukan pada saat mengalami permasalahan yang sama. Masing-masing anggota kelompok saling memberikan penguatan dan mendukung satu sama lain. Hal inilah menyebabkan perasaan cemas yang mereka alami sebelumnya menjadi menurun. Dengan demikian, dapat disimpulkan bahwa terapi suportif merupakan psikoterapi yang efektif untuk menurunkan kecemasan keluarga merawat anak retardasi mental ringan.

Pengaruh Terapi Suportif Terhadap Motivasi Keluarga Dalam Merawat Anak Retardasi Mental Ringan 
Rizka. Y, Pengaruh Terapi Suportif Terhadap Kecemasan Dan Motivasi Keluarga Dalam Merawat Anak Retardasi Mental Ringan Di Slb Dharma Asih Kraksaan Probolinggo Berdasarkan pada tabel 4 diperoleh mempengaruhi motivasi keluarga dalam hasil bahwa skor motivasi keluarga dalam merawat anak retardasi mental ringan sebelum diberikan terapi suportif sebesar 18,97. Hal ini dikarenakan sebagian besar responden mengalami penurunan motivasi dalam merawat anak retardasi mental ringan. Hal ini dikarenakan responden sering kali mengalami keputusasaan ketika mengajari anak menulis dan membaca, merasa jengkel saat anak berperilaku hiperaktif dan tantrum, serta merasa khawatir terhadap masa depan anak ketika anak menolak untuk mengikuti pembelajaran dikelas.

Hasil penelitian tersebut serupa dengan Mbwilo, Smide dan Aarts (2010) yang menyatakan bahwa keluarga mengalami penurunan motivasi merawat anak retardasi mental disebabkan karena mereka tidak mendapatkan dukungan dengan baik ketika merawat anak. Akibatnya terdapat beberapa anak yang tidak menerima perawatan kesehatan secara memadai seperti anak dipaksa untuk berada didalam rumah dan dilarang bermain dengan teman sebayanya. Selain itu, keluara merasa lelah karena anak tidak dapat merawat dan menjaga kebersihan diri secara mandiri. merawat anak retardasi mental ringan. Seperti yang diungkapkan oleh Haque, Haque dan Shamimul (2014) menguraikan bahwa motivasi dapat diartikan sebagai suatu kondisi perasaan atau pemikiran yang menggerakkan dan mendorong hati seseorang untuk melakukan suatu pekerjaan atau tindakan dengan bersungguh-sungguh sehingga dapat mencapai tujuan tertentu yang diinginkan. Seseorang yang mampu memberikan kepuasan terhadap orang lain maka dapat dikategorikan bahwa seseorang tersebut mempunyai tingkat motivasi yang adekuat.

Hal tersebut serupa dengan yang diungkapkan oleh Vitai (2016) menyatakan bahwa seseorang dapat dikatakan memiliki motivasi apabila mampu menyediakan waktu dan energi lebih untuk membantu memenuhi segala kebutuhan dasar orang lain. Begitu pula termasuk memenuhi kebutuhan dasar pada anak yang mengalami disabilitas juga menjadi suatu kewajiban yang harus dipenuhi terutama oleh keluarga. Tentunya, pemenuhan kebutuhan tersebut dapat dinilai dengan dominannya tindakan yang dilakukan keluarga.

Dengan demikian, untuk mengatasi

Seluruh permasalahan tersebut tentunya menjadi beban psikologis terutama bagi keluarga sehingga dapat seluruh permasalahan yang ada, maka dibutuhkan alternatif segera salah satunya yakni memberikan psikoterapi. Psikoterapi 
Rizka. Y, Pengaruh Terapi Suportif Terhadap Kecemasan Dan Motivasi Keluarga Dalam Merawat Anak Retardasi Mental Ringan Di Slb Dharma Asih Kraksaan Probolinggo sangatlah dibutuhkan oleh keluarga agar dapat menjadi sumber dukungan sosial dapat meningkatkan koping keluarga utama. Menurut Young dalam melakukan proses adaptasi sehingga mereka mampu menerima kehadiran anak retardasi mental ringan sepenuhnya (Shedler, 2010). Psikoterapi yang dimaksud tersebut yaitu melalui pemberian terapi suportif.

Berdasarkan pada tabel 7 diperoleh bahwa hasil skor motivasi keluarga dalam merawat anak retardasi mental ringan sesudah diberikan terapi suportif mengalami peningkatan sebesar 23,32 menjadi 42,29. Selain itu, sesuai dengan hasil uji paired t-test didapatkan nilai signifikansi sebesar $\rho=0,000$ sehingga $\rho \leq 0,05$. Dengan demikian dapat disimpulkan bahwa terdapat pengaruh terapi suportif terhadap motivasi keluarga dalam merawat anak retardasi mental ringan.

Hasil penelitian tersebut serupa dengan Buckley, Maayan, Weiser dan Adams (2015) menguraikan bahwa terapi suportif juga efektif untuk diberikan kepada individu yang mengalami skizofrenia. Melalui terapi suportif setiap individu diberikan kesempatan untuk mengutarakan seluruh kendala dan hambatan yang dialami saat merawat klien skizofrenia sehingga mereka dapat bertukar pengalaman dengan anggota lain. Individu yang saling bertukar pengalaman menguraikan bahwa sekelompok orang yang mempunyai masalah yang sama berkumpul dapat mengurangi beban yang dirasakan caregiver sehingga dapat meningkatkan motivasi untuk menghadapi situasi sulit.

Selain itu, seperti yang diungkapkan Chien, Mui, Cheung dan Gray (2015) menguraikan bahwa melalui adanya kegiatan bertukar pengalaman yang menjadi fokus utama dari terapi suportif ini ternyata efektif untuk dapat membantu mengubah sudut pandang seseorang yang semula menilai situasi tertentu secara negatif dapat dirubah menjadi positif. Chien dan Chan (2013) mengutarakan bahwa mutual support sangatlah diperlukan kepada individu yang harus memberikan perawatan seumur hidup kepada orang lain. Mutual support diartikan sebagai bentuk menyelesaikan masalah melalui diskusi sehingga dapat berbagi pikiran, pendapat dan umpan balik dari pengalaman yang telah dialami sebelumnya. Dengan demikian dapat menjadi solusi bagi orang lain sehingga termotivasi kembali untuk menyelesaikan masalah.

Situsi tersebut menggambarkan bahwa ketika seseorang merasa cemas, khawatir, dan gelisah ketika harus merawat 
Rizka. Y, Pengaruh Terapi Suportif Terhadap Kecemasan Dan Motivasi Keluarga Dalam Merawat Anak Retardasi Mental Ringan Di Slb Dharma Asih Kraksaan Probolinggo anak retardasi mental ringan seorang diri mengembangkan terapi suportif yang maka sangatlah berpengaruh terhadap motivasi dalam memberikan perawatan. Namun, berbeda ketika individu yang sama-sama memiliki anak dengan retardasi ditujukan kepada guru SLB. Hal ini disebabkan guru SLB merupakan pihak terdekat anak retardasi mental ringan ketika berada disekolah.

mental ringan berkumpul maka mereka mendapatkan informasi cara merawat anak yang mengalami disabilitas dan mendapatkan dukungan emosional. Kondisi ini menyebabkan individu mendapatkan semangat baru sehingga dapat meningkatkan motivasi untuk mampu memberikan pelayanan perawatan terbaik bagi anak retardasi mental ringan.

\section{Kesimpulan}

Terdapat pengaruh terapi suportif terhadap kecemasan keluarga dalam merawat anak retardasi mental ringan dengan nilai signifikansi sebesar $\rho=0,000$. Selain itu, juga terdapat pengaruh terapi suportif terhadap motivasi keluarga dalam merawat anak retardasi mental ringan dengan nilai signifikansi sebesar $\rho=0,000$

\section{Saran}

Berdasarkan hasil penelitian yang telah dilakukan maka saran yang dapat diuraikan adalah terapi suportif menjadi salah satu bentuk psikoterapi yang efektif dalam menurunkan kecemasan dan meningkatkan motivasi keluarga merawat anak retardasi mental ringan. Oleh karena

\section{Referensi}

Abedin, A., \& Molaie, A. (2010). The effectiveness of Group Movie Therapy (GMT) on parental stress reduction in mothers of children with mild mental retardation in Tehran. Social and Behavioral Sciences, 5, 988-993.

Azeem, M. W., Dogar, I. A., Shah, S., Cheema, M. A., Asmat, A., Akbar, M., . . Haider, I. I. (2013). Anxiety and Depression among Parents of Children with Intellectual Disability in Pakistan. J Can Acad Child Adolesc Psychiatry, 22(4), 290-295.

Brook, A. W. (2014). Get excited: Reappraising pre-performance anxiety as excitement. Journal of Experimental Psychology: General, 143(3), $1144 \quad-1158 . \quad$ doi: 10.1037/a0035325

Buckley, L. A., Maayan, N., Weiser, K. S., Adams, C. E. (2015). Supportive therapy for schizophrenia. Cochrane Database of Systematic Reviews, 4: 1-9. 
Rizka. Y, Pengaruh Terapi Suportif Terhadap Kecemasan Dan Motivasi Keluarga Dalam Merawat Anak Retardasi Mental Ringan Di Slb Dharma Asih Kraksaan Probolinggo

Chien, W. T., Chan, S. W. C. (2013). The effectiveness of mutual support group intervention for Chinese families of people with schizophrenia: A randomised controlled trial with 24-month follow-up. International Journal of Nursing Studies. 50(10): 1326-1340.

Chien, W. T., Mui, J. H. C., Cheung, E. F. C., Gray, R. (2015). Effects of motivational interviewing-based adherence therapy for schizophrenia spectrum disorders: A randomized controlled trial. BioMed Central. 16: 270 .

Ganzory, G. S. E., Matty, G. M. A. E., \& Reheem, M. A. E. (2013). Effect of Counseling on Patterns of Care, Stress and Life Burden on Parents of Mentally Retarded Children. Life Science Journal 10(3), 1850 -1858.

Gohel, M., Mukherjee, S., \& Choudhary, S. K. (2011). Psychosocial impact on the parents of mentally retarded children in Anand District. Heathline, 2(2), 62-66.

Gonca, K. M. \& Deniz, S. (2016). The effectiveness of structured supported education programs for families with intellectually disabled children. Turkey: The Example of Turkey.

Haque, M. F., Haque, M. A., Shamimul, I. M. (2014). Motivational theories: A
Critical Analysis. ASA University Review, 8(1): 61-68.

Hosseinkhanzadeh, A. A., Yeganeh, T., Rashidi, N., Zareimanesh, G., \& Fayeghi, N. (2013). Effects of stress management training by using cognitive-behavioral method on reducing anxiety and depression among parents of children with mental retardation. Scientific Research, 3(1), 62-66. doi: 10.4236/sm.2013.31011

Jenaabadi, H. (2014). The study and comparison of stress levels and coping strategies in parents of exceptional (mentally retarded, blind and deaf) and normal children in Zahedan. Social and Behavioral Sciences, 114, 197-202. doi: 10.1016/j.sbspro.2013.12.684

Karasavvidis, S., Avgerinou, C., Lianou, E., Priftis, D., Lianou, A., \& Siamaga, E. (2011). Mental Retardation and Parenting Stress. International Journal of Caring Sciences 4(1), 21-31.

Katalinic, S., Jengic, V. S., Pavelic, M. S., \& Zudenigo, S. (2012). Reproductive rights of mentally retarded persons. Psychiatria Danubina, 24(1), 38-43 Kementrian Kesehatan Republik Indonesia. (2014). Kesehatan Anak dengan Disabilitas. Jakarta: 
Rizka. Y, Pengaruh Terapi Suportif Terhadap Kecemasan Dan Motivasi Keluarga Dalam Merawat Anak Retardasi Mental Ringan Di Slb Dharma Asih Kraksaan Probolinggo Kementrian Kesehatan Republik International Journal of Scientific Indonesia. and Research Publications, 2(6), 1-5.

Kerenhappachu, M. S., \& Sridevi, G. (2014). Care giver's burden and perceived social support in mothers of children with mental retardation. International Journal of Scientific and Research Publications, 4(4), 1-7.

Klingberg, S., Jakobi, U. E., Wittorf, A. (2010). Supportive therapy for schizophrenic disorders. Verhaltenstherapie, 20: 167-174.

Mbwilo, G. S. K., Smide, B., \& Aarts, C. (2010). Family perceptions in caring for children and adolescents with mental disabilities: a qualitative study from Tanzania. Tanzania Journal of Health Research, 12(2), $1-12$.

Ramakrishna, B., Bhagya, A. (2013). Prevalence of mental retardation among children In Mangalore. Nitte University Journal of Health Science, 3(4): 21-28.

Rohini. (2012). Management of anxiety and qol in the parents of children with special needs throughpositive therapy. International Journal of Multidisciplinary Research 2(6), 7580.

Roy, B. (2012). Adjustment problems of Educable Mentally Retarded.
Sadock, B. J., \& Sadock, V. A. (2010). Buku ajar psikiatti klinis (2nd ed.). Jakarta: EGC.

Sari, P. A., Jumaini, \& Hasanah, O. (2013). Hubungan konsep diri orang tua dengan motivasi dalam merawat anak retardasi mental. Repository, 1(1), 1-10.

Shedler. J. (2010). The efficacy of psychodynamic psychotherapy. American Psychologist, 65(2): 98109.

Shenai, N. G., Wadia, D. N. (2014). Development of a self care skills scale for children with developmental disorders. The Indian Journal of Occupational Therapy, 46(1): 16-21.

Singh, K., Kumar, R., Sharma, N., Nehra, D. K. (2014). Study of burden in parents of children with mental retardation. Journal of Indian Health Psychology, 8(2): 13-20.

Singh, U., Sweta, K., Kiran, M. (2017). Effectiveness of supportive therapy on quality of life among person with chronic schizophrenia: A randomized control trial. Indian Journal of Psychiatric Social Work, 8(1): 21-27.

Solanki, J., Khetan, J., Gupta, S., Tomar, D., \& Singh, M. (2015). Oral 
Rizka. Y, Pengaruh Terapi Suportif Terhadap Kecemasan Dan Motivasi Keluarga Dalam Merawat Anak Retardasi Mental Ringan Di Slb Dharma Asih Kraksaan Probolinggo rehabilitation \& management of Concepts of care in evidence-based metally retarted. Journal of Clinical and Diagnostic Research, 9(1), 1-6. doi:10.7860/JCDR/2015/11077.5415

Solomon, M. D. (2015). A study on depression, anxiety and stress among the parents of differently able children. International Journal on Recent and Innovation Trends in Computing and Communication 3(2), 476-480.

Stuart, G. W. (2013). Principles and practice of psychiatric nursing (10th ed.). Missouri: Elsevier Inc.

Tavakolizadeh, J., Dashti, S., \& Panahi, M. (2012). The effect of rationalemotional training on mothers' mental health condition of children with mental retardation. Social and Behavioral Sciences, 69, 649 - 658. doi: 10.1016/j.sbspro.2012.11.457

Tillery, M. T., \& Fishbach, A. (2011). The course of motivation. Journal of Consumer Psychology, xx, 1-10. doi: 10.1016/j.jcps.2011.04.004.

Townsend, M. C. (2014). Essentials of psychiatric mental health nursing: 